\title{
Kualitas Perairan Situ Gintung, Tangerang Selatan
}

\author{
SAIFUL BAHRI $^{1}$, FIRDAUS RAMADHAN ${ }^{1}$, INDHINA REIHANNISA ${ }^{1}$ \\ ${ }^{1}$ Jurusan Biologi, Fakultas Sains dan Teknologi, UIN Syarif Hidayatullah Jakarta \\ J1. Ir. H. Juanda No. 95 Ciputat 15412 \\ email: firdausramadhan213@gmail.com
}

\begin{abstract}
Situ Gintung is lake located in East Ciputat regional, South Tangerang City. Various activity of human such as building residence, floating net cages, fishing and disposal waste from buildings around lake had changed aquatic function in Situ Gintung that arriving allegedly decreased and not compatible with government regulation RI number 82 year 2001 on water quality management and water pollution control. The aimed of this research is perceiving water quality of Situ Gintung based on physical, chemical, and microbiological aquatic as well as find pathogenic bacteria in Situ Gintung aquatic. Parameters of physical chemistry which were measured was the degree of acidity $(\mathrm{pH})$, dissolved oxygen (DO), five day biochemical oxygen demand ( $\left.\mathrm{BOD}_{5}\right)$, total dissolved solids (TDS) using Water Quality Checker (WQC) while metal components parameter was $\mathrm{Fe}$ and $\mathrm{Cu}$ using Atomic Absorption Spectrofotometre (AAS). Microbiology test form was total colliform with Most Probable Number (MPN) and biochemistry for pathogen bacteria. The temperature parameter, content of $\mathrm{DO}$ and are below the quality standard, while parameters such as $\mathrm{BOD}_{5}$ and $\mathrm{pH}$ is in the quality of the raw differences 3.11 to $6.49 \mathrm{mg} / 1$ and 4 to 6.51 . Total collifom bacteria value in every station is outside air quality standard class one, $>1100$ cell/100 ml. Based on Physical, Chemical and Microbiological water Situ Gintung no longer corresponded to water class one PP number 82 year 2001 and there are seven strains of Salmonella sp. bacteria in every station except Station 6.
\end{abstract}

Keywords: aquatic quality, Coliform bacteria, pathogenic bacteria, Situ Gintung, water standard

\section{PENDAHULUAN}

Air merupakan salah satu sumber energi yang dibutuhkan oleh semua makhluk hidup untuk proses fisiologis maupun non fisiologis. Ketersediaan air secara kualitas, jumlah dan berkelanjutan dari sumber air baku yang dapat diolah menjadi air bersih merupakan hal yang penting. Sumber air baku yang dapat digunakan untuk penyediaan air bersih yaitu air hujan, air permukaan (air sungai, air danau, situ dan rawa) dan air tanah (air tanah dangkal, air tanah dalam dan mata air). Padatnya penduduk di daerah perkotaan menyebabkan air bersih mulai sulit diperoleh, karena telah terjadi banyak pencemaran pada beberapa sumber air baku daerah perkotaan (Suriawiria, 2008). Aktivitas manusia telah menyebabkan penurunan kualitas air pada beberapa perairan sebelumnya (Huang et al., 2006; Manuaba, 2007; Hoorman et al., 2008; Sener et al., 2013).

Situ Gintung merupakan situ yang berada di kawasan Ciputat Timur, Kota Tangerang
Selatan. Situ ini memiliki luas 21,49 ha dan diperkirakan mampu menampung I juta $\mathrm{m}^{3}$ air (Peraturan Daerah Kota Tangerang Selatan No 15, 2011). Besar daya tampung tersebut dapat dimanfaatkan sebagai sumber air baku yang dapat diolah untuk memenuhi kebutuhan rumah tangga terutama sebagai air minum. Pembangunan pemukiman yang pesat menyebabkan alih fungsi lahan sekitar 9.51 ha. Penurunan luas perairan yang diikuti dengan terus bertambahnnya beban cemaran pada perairan menyebabkan penurunan kemampuan self-purification perairan. Berbagai aktivitas manusia seperti membangun pemukiman, keramba jaring apung, memancing dan menjadikan situ sebagai tempat buangan limbah dari bangunan sekitar situ telah mengubah fungsi perairan di Situ Gintung.

Akibat aktivitas tersebut kualitas air di Situ Gintung diduga menurun dan tidak sesuai dengan baku mutu air baku (air kelas I) yang telah ditetapkan oleh Peraturan Pemerintah RI No.82 Tahun 2001 tentang Pengelolaan 
Kualitas Air dan Pengendalian Pencemaran Air. Penurunan kualitas dapat terjadi mulai dari berubahnya sifat fisik (suhu dan TDS), kimia ( $\mathrm{pH}, \mathrm{DO}, \mathrm{BOD}_{5}$ dan logam berat) dan mikrobiologi seperti kehadiran bakteri Coliform dan bakteri patogen lain seperti Salmonella sp. dan Shigella sp. dalam perairan. Berdasarkan maslaha tersebut perlu dilakukan pengujian untuk mengetahui kualitas air perairan Situ Gintung meliputi faktor fisik, kimia, dan mikrobiologi.

\section{METODE}

Penelitian dilakukan pada AgustusOktober 2013. Pengambilan sampel air dilakukan pada musim kemarau di Situ Gintung, Ciputat, Tangerang Selatan. Penentuan stasiun pengambilan data ditentukan dengan metode purposive sampling berdasarkan rona lingkungan. Stasiun 1 (inlet perairan) S $6^{\circ} 18^{\prime} 38.2^{\prime \prime}$ E $106^{\circ} 45^{\prime} 39.2^{\prime \prime}$, stasiun 2 (daerah termanfaatkan keramba jaring apung padat pemukiman) S $6^{\circ} 18^{\prime} 27.58^{\prime \prime}$ E $106^{\circ} 45^{\prime} 40.89^{\prime \prime}$, stasiun 3 (inlet perairan) S $6^{\circ} 18^{\prime} 15.7^{\prime \prime}$ E $106^{\circ} 45^{\prime} 48^{\prime \prime}$ stasiun 4 (daerah termanfaatkan keramba jaring apung sekitar taman wisata) S 6 $18^{\prime} 30.19^{\prime \prime}$ E $106^{\circ} 45^{\prime} 51.01$ ', stasiun 5 (outlet perairan) S $6^{\circ} 18^{\prime} 6.1$ ” E $106^{\circ} 45^{\prime} 47.4$ " dan stasiun 6 (daerah tengah) S 618'14.68' E $106^{\circ} 45^{\prime} 45.37$ '.

Pengambilan sampel menggunakan water bottle sampler pada kedalaman 0 meter. Pengujian logam dan fisik-kimia air dilakukan di Laboratorium Lingkungan dan Pengujian total coliform dan fecal coliform dilakukan di Laboratorium Mikrobiologi Pusat Laboratorium Terpadu (PLT) UIN Syarif Hidayatullah Jakarta.

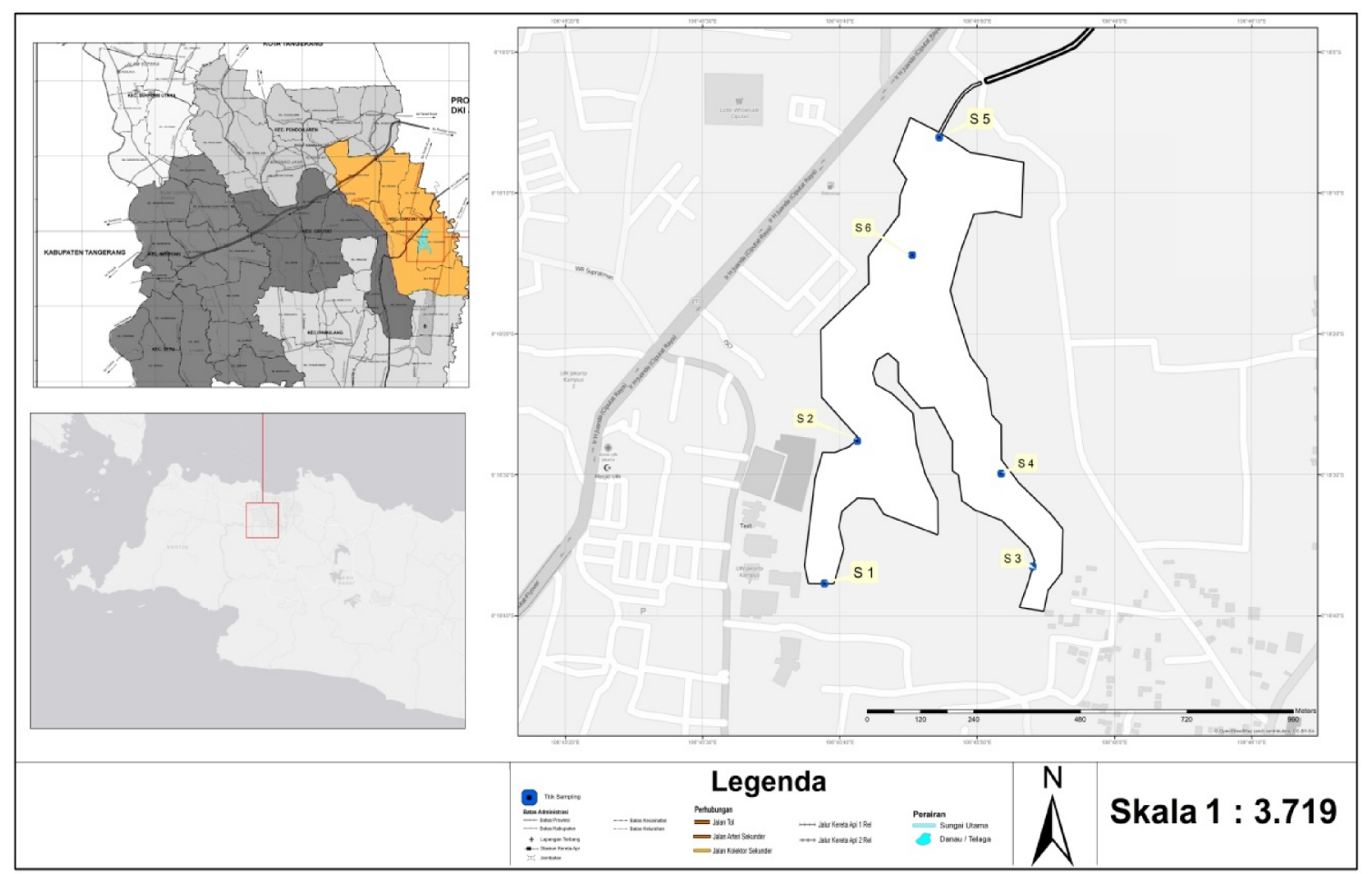

Gambar 1. Peta lokasi pengambilan sampel Situ Gintung

Pengukuran kualitas fisik-kimia air seperti suhu, TDS, $\mathrm{pH}$ dan DO dengan menggunakan WQC (Horiba). Pengukuran kebutuhan oksigen biologi lima hari $\left(\mathrm{BOD}_{5}\right)$ berdasarkan Jouanneau et al. (2014). Pengujian logam besi (Fe) dan tembaga $(\mathrm{Cu})$ menggunakan Spektrofotometer Serapan Atom (Perkin
Elmer Analyst 700). Pengujian total coliform menggunakan most probable number (MPN) seri tiga tabung $(10 \mathrm{ml}, 1 \mathrm{ml}$ dan $0,1 \mathrm{ml})$ yang mengacu tabel Hopkin. Keberadaan bakteri pathogen seperti Salmonella dan Shigella dianalisa secara kualitatif dengan uji biokimia. Hasil dibandingkan dengan air baku kelas I PP. 
No. 82 Tahun 2001 tentang Pengelolaan Kualitas Air dan Pengendalian Pencemaran Air untuk Penentuan Kualitas Perairan.

\section{HASIL}

Fisik-Kimia Perairan. Hasil pengukuran kualitas fisik-kimia pada perairan Situ Gintung (Tabel 1). Kisaran suhu air pada setiap stasiun Situ Gintung berkisar antara $27.59-30.17^{\circ} \mathrm{C}$. Nilai tersebut masih berada pada kisaran baku mutu untuk air kelas I berdasarkan PP. No. 82 Tahun 2001. Pengukuran TDS pada setiap stasiun diperoleh kisaran antara 87 - $195 \mathrm{mg} / \mathrm{l}$, kisaran nilai tersebut masih kriteria air tawar. Nilai DO di setiap stasiun penelitian berkisar antara $7.49-8.52 \mathrm{mg} / \mathrm{l}$. Nilai tersebut masih berada di kisaran baku mutu untuk air kelas satu berdasarkan PP. No. 82 Tahun 2001. Nilai kisaran nilai $\mathrm{pH}$ yaitu $4.89-6.51$. Nilai $\mathrm{pH}$ terendah terdapat pada stasiun 1 yaitu 4.89 diikuti oleh stasiun $2,3,4,5$ dan nilai $\mathrm{pH}$ tertinggi terdapat pada stasiun 6 yaitu 5.29, 5.38, 5.47, 5.7 dan 6.51. Nilai $\mathrm{pH}$ semua stasiun kecuali stasiun 6 berada di luar kisaran baku mutu air kelas satu PP. No. 82 Tahun 2001.

Tabel 1. Hasil pengukuran fisik dan kimia pada setiap stasiun pada perairan Situ Gintung

\begin{tabular}{ccccccccc}
\hline \multirow{2}{*}{ No } & \multirow{2}{*}{ Parameter } & \multirow{2}{*}{ Baku Mutu* } & \multicolumn{6}{c}{ Stasiun } \\
\cline { 3 - 8 } & & 1 & 2 & 3 & 4 & 5 & 6 \\
\hline 1 & Suhu Air $\left({ }^{\circ} \mathrm{C}\right)$ & Deviasi 3 Suhu Udara & 27.59 & 28.47 & 28.62 & 30.17 & 29.15 & 28.31 \\
2 & TDS $(\mathrm{mg} / \mathrm{L})$ & 1000 & 150 & 117 & 195 & 123 & 124 & 87 \\
3 & $\mathrm{DO}(\mathrm{mg} / \mathrm{L})$ & 6 & 8.22 & 8.18 & 8.21 & 7.49 & 7.92 & 8.52 \\
4 & $\mathrm{pH}$ & $6-9$ & 4.89 & 5.29 & 5.38 & 5.47 & 5.7 & 6.51 \\
5 & $\mathrm{BOD}_{5}(\mathrm{mg} / \mathrm{L})$ & 2 & 6.49 & 5.56 & 4.35 & 4.7 & 3.57 & 3.11 \\
6 & $\mathrm{Fe}(\mathrm{mg} / \mathrm{L})$ & 0.3 & 0.02 & $\mathrm{ND}^{*}$ & 0.16 & 0.003 & $\mathrm{ND}^{*}$ & $\mathrm{ND}^{*}$ \\
7 & $\mathrm{Cu}(\mathrm{mg} / \mathrm{L})$ & 0.02 & $\mathrm{ND}^{*}$ & $\mathrm{ND}^{*}$ & $\mathrm{ND}^{*}$ & $\mathrm{ND}^{*}$ & $\mathrm{ND}^{*}$ & $\mathrm{ND}^{*}$ \\
\hline
\end{tabular}

Ket: *PP No. 82 Tahun 2001 Tentang Pengelolaan Kualitas Air dan Pengendalian Pencemaran Air *ND : Not Detected

Hasil pengukuran kadar logam Fe yang terdeteksi pada stasiun 1, 3 dan 4 yaitu masing masing 0.02, 0.16 dan $0.003 \mathrm{mg} / \mathrm{l}$. Nilai Fe pada stasiun 2, 5 dan 6 tidak terdeteksi karena konsentrasi terlalu rendah (di bawah batas deteksi minimum). Nilai Fe pada setiap stasiun berada di bawah nilai baku mutu air kelas I PP. No. 82 Tahun 2001. Nilai logam tembaga $(\mathrm{Cu})$ pada setiap stasiun di perairan diperoleh hasil tidak terdapat logam tersebut dalam perairan, sehingga air di setiap stasiun masih berada di bawah baku mutu kelas 1 berdasarkan Peraturan Pemerintah Nomor 82 Tahun 2001.

Coliform dan Bakteri Patogen. Hasil pengujian total coliform pada setiap stasiun pengamatan disajikan pada Tabel 2. Jumlah semua bakteri total coliform pada setiap stasiun yaitu $>1100 \mathrm{sel} / 100 \mathrm{ml}$, hal ini menunjukkan bahwa semua air di stasiun telah tercemar bakteri total coliform. Berdasarkan PP. No. 82 Tahun 2001 semua stasiun berada di luar nilai baku mutu air kelas I.

Tabel 2. Hasil uji pendugaan pada metode MPN perairan Situ Gintung

\begin{tabular}{ccccc}
\hline \multirow{2}{*}{ Sampel stasiun ke - } & \multicolumn{3}{c}{ Hasil positif dari setiap tabung } & \multirow{2}{*}{ Jumlah koloni per $100 \mathrm{ml}$} \\
\cline { 2 - 4 } & 3 dari $10 \mathrm{ml}$ & 3 dari $1 \mathrm{ml}$ & 3 dari $0,1 \mathrm{ml}$ & $>1100$ \\
\hline 1 & 3 & 3 & 3 & $>1100$ \\
2 & 3 & 3 & 3 & $>1100$ \\
3 & 3 & 3 & 3 & $>1100$ \\
4 & 3 & 3 & 3 & $>1100$ \\
5 & 3 & 3 & 3 & $>1100$ \\
6 & 3 & 3 & 3 & \\
\hline
\end{tabular}


Hasil uji kualitatif keberadaan bakeri pathogen diperoleh 12 isolat dari semua stasiun (Tabel. 3).

Berdasarkan pengamatan morfologi dan biokimia diperoleh 5 isolat yaitu $1 \mathrm{H}$, II P, II $\mathrm{H}$, III H, IV H, V P dan V H yang memiliki karakteristik bakteri genus Salmonella. Isolat tersebut memiliki morfologi koloni berwarna transparan sampai merah muda dengan atau tanpa titik hitam, besar koloni rata-rata 2-4 $\mathrm{mm}$, bulat dengan pinggir utuh. Ciri biokimia dari semua isolat yaitu tidak menghasilkan $\mathrm{H}_{2} \mathrm{~S}$, memberikan hasil negatif pada uji indol, hasil positif pada metil merah, negatif pada voges proskauer, positif sitrat dan menghasilkan enzim katalase.

Tabel 3. Hasil pengujian biokimia isolat bakteri pada setiap stasiun di Situ Gintung

\begin{tabular}{llccccccc}
\hline No. & Isolat & Uji $\mathrm{H}_{2} \mathrm{~S}$ & $\begin{array}{c}\text { Produksi } \\
\text { Indol }\end{array}$ & $\begin{array}{c}\text { Reaksi } \\
\text { MR }\end{array}$ & $\begin{array}{c}\text { Reaksi } \\
\text { VP }\end{array}$ & Sitrat & Katalase & $\begin{array}{c}\text { Hasil Identifikasi } \\
\text { (Terduga) }\end{array}$ \\
\hline 1. & I P & - & - & + & - & + & + & $\#$ \\
2. & I H & + & - & + & - & + & + & Salmonella \\
3. & II P & + & - & + & - & + & + & Salmonella \\
4. & II H & + & - & + & - & + & + & Salmonella \\
5. & III P & - & - & - & - & + & + & Pseudomonas \\
6. & III H & + & - & + & - & + & + & Salmonella \\
7. & IV P & - & - & + & - & + & + & $\#$ \\
8. & IV H & + & - & + & - & + & + & Salmonella \\
9. & V P & + & - & + & - & + & + & Salmonella \\
10. & V H & + & - & + & - & + & + & Salmonella \\
11. & VI P & - & - & + & - & + & + & $\#$ \\
12. & VI H & + & - & - & - & + & + & $\#$ \\
\hline
\end{tabular}

Ket : (+) hasil uji positif, (-) hasil uji negatif dan (\#) hasil uji meragukan dan perlu dilakukan uji lanjutan

\section{PEMBAHASAN}

Fisik dan Kimia Perairan. Beberapa faktor yang mempengaruhi suhu di perairan adalah intensitas cahaya matahari dan keberadaan vegetasi terrestrial sekitar perairan (Yazwar, 2008). Nilai TDS pada stasiun inlet perairan atau stasiun dengan keramba jaring apung umumnya memiliki nilai yang tinggi dibandingkan stasiun yang jauh dari keduanya. Stasiun 3 dan 1 merupakan inlet yang memiliki nilai TDS lebih tinggi dibanding semua stasiun yaitu $195 \mathrm{mg} / \mathrm{l}$ dan $150 \mathrm{mg} / \mathrm{l}$, hal ini disebabkan adanya masukan aliran sungai yang membawa ion-ion anorganik seperti sodium, kalsium, sulfat, bikarbonat dan lain lain (Crowe et al., 2008). Hal ini berbeda dengan stasiun 6 yang merupakan bagian tengah danau memiliki nilai TDS terendah dibandingkan semua stasiun yaitu $87 \mathrm{mg} / \mathrm{l}$. Rendahnya nilai TDS di stasiun 6 disebabkan lokasinya yang jauh dari aktivitas manusia dan jauh dari inlet sehingga beban masukan ion-ion anorganik lebih rendah. Hal ini sesuai dengan hasil penelitian Yazwar (2008) yang melaporkan nilai TDS perairan Prapat Danau Toba lebih tinggi pada stasiun dengan aktivitas manusia yang tinggi dibandingkan dengan daerah tengah atau jauh dari aktivitas manusia. Nilai TDS yang tinggi (1001-10000 mg/l) dapat menyebabkan perairan memiliki salinitas dan mempengaruhi fisiologis organisme di dalam perairan air tawar (Kazi et al., 2009).

Kisaran nilai DO perairan Situ Gintung merupakan nilai yang umum di perairan lentik (Salmin, 2005). Nilai DO pada stasiun 6 lebih tinggi dibandingkan stasiun lainnya yaitu 8.52 $\mathrm{mg} / \mathrm{l}$ karena jauh dari aktivitas manusia baik masukan limbah atau keramba jaring apung. Rendahnya aktivitas manusia menyebabkan proses fotosintesis dari fitoplankton berjalan dengan baik, suhu rendah sehingga meningkatkan kelarutan oksigen dalam air tinggi. Oksigen dari atmosfer akan lebih 
mudah berdifusi tidak hanya pada suhu rendah, tetapi tanpa ada penghalang seperti padatan terlarut, buih busa ataupun minyak. Stasiun 4 memiliki nilai DO terendah yaitu, $7.49 \mathrm{mg} / \mathrm{l}$. Nilai DO stasiun 4 lebih rendah dibandingkan yang lain karena adanya keramba jaring apung. Sisa pakan akan terakumulasi dan didegradasi oleh bakteri heterotrofik dan mikroorganisme secara aerob sehingga mengurangi konsentrasi oksigen terlarut di perairan (Pujiastuti et al., 2013).

Situ Gintung telah mengalami penurunan nilai $\mathrm{pH}$ pada perairannya. Pada tahun 2002 nilai $\mathrm{pH}$ berkisar antara 5.67-7.83. Stasiun yang berada sekitar inlet dan keramba jaring apung memiliki $\mathrm{pH}$ yang rendah karena kedua lokasi tersebut selalu mendapat masukan senyawa organik baik limbah domestik, air lindi (leachate) dan sisa pakan yang tidak terkonsumsi. Senyawa organik tersebut didegradasi oleh mikroorganisme dan menghasilkan asam-asam organik sehingga menurunkan pH perairan (Yazwar, 2008). Berbeda pada stasiun yang jauh dari inlet dan keramba jaring apung memiliki nilai $\mathrm{pH}$ lebih tinggi karena beban masukan rendah dan terjadi proses pengendapan sehingga senyawa organik berada pada dasar perairan.

Nilai $\mathrm{BOD}_{5}$ merupakan nilai kebutuhan oksigen yang digunakan mikoorganisme untuk mengurai senyawa organik yang ada di perairan selama lima hari. Pengujian nilai $\mathrm{BOD}_{5}$ merupakan salah satu parameter penting dalam suatu perairan. Tingginya nilai $\mathrm{BOD}_{5}$ diindikasikan perairan tersebut telah tercemar senyawa organik (Emongor et al., 2005; Salmin, 2005; Kazi et al., 2009; Sitorus, 2009; Jouanneau et al., 2014). Tingginya nilai $\mathrm{BOD}_{5}$ disebabkan oleh banyaknya cemaran senyawa organik pada setiap stasiun perairan. Stasiun yang berada di sekitar inlet dan keramba jaring apung seperti stasiun 1, 3, 2 dan 4 umumnya memiliki cemaran yang tinggi karena terus menerima masukan senyawa organik di dalamnya. Keramba jaring apung yang tidak ramah lingkungan juga akan memberikan cemaran bahan organik di perairan (Zulkarnain et al., 2006; Pudjiastuti et al., 2013). Berbeda dengan stasiun 5 dan stasiun 6 yang merupakan daerah outlet dan tengah memiliki nilai $\mathrm{BOD}_{5}$ lebih rendah dibandingkan stasiun lainnya karena jauh dari aktivitas manusia. Sener et al., (2013) melaporkan perairan yang di sekitarnya terdapat aktivitas manusia yang tinggi memiliki nilai BOD lebih tinggi dibandingkan yang tidak. Kenaikan nilai $\mathrm{BOD}_{5}$ juga disebabkan oleh keadaan musim. Nilai $\mathrm{BOD}_{5}$ pada musim kemarau lebih tinggi dibandingkan musim penghujan telah dilaporkan oleh Ajeagah et al., (2014). Hal ini disebabkan tidak adanya pengenceran atau penurunan kandungan senyawa organik oleh air hujan pada perairan.

Kehadiran unsur Fe dalam air bersih dapat menimbulkan bau logam, dengan indikasi warna koloid merah (karat) dalam air akibat oksidasi oleh oksigen terlarut dan dapat menjadi racun bagi manusia. Keberadaan $\mathrm{Fe}$ yang tinggi mendukung pertumbuhan mikroorganisme seperti Cronothrix sp. dan Clonothrix sp. yang dapat menimbulkan bau tidak sedap (Said, 2005). Tembaga (Cu) merupakan logam berat yang bersifat racun. Keberadaan $\mathrm{Cu}$ dalam perairan dapat terakumulasi di dalam rantai makanan dan menimbulkan efek yang berbahaya (Rochyatun, 2006; Sahara, 2009). Ion-ion logam berat dapat bereaksi dengan gugus sel. Logam berat juga memiliki daya oligodinamik yaitu memiliki daya bunuh pada konsentrasi rendah (Suriawiria, 2008).

\section{Coliform dan Bakteri Patogen.}

Beberapa genus bakteri yang tergolong total coliform bakteri adalah Aerobacter, Citrobacter, Enterobacter, Escherichia, Hafnia, Klebisella, Serratia, and Yersinai. Keberadaan bakteri total coliform tidak selalu mengindikasi telah terjadi pencemaran materi fekal karena bakteri tersebut hidup di perairan dan tanah, namun angka total coliform bakteria yang tinggi mengindikasikan adanya cemaran fekal coliform karena 97\% dari populasi bakteri total coliform adalah bakteri fekal coliform (Gerardi, 2006). Bakteri fekal coliform yang umum digunakan sebagai indikator pencemaran fekal adalah Escherichia coli dengan ciri berbentuk batang lurus (Straight rod), tidak berspora, dan gram negatif. Bakteri ini merupakan indikator pencemaran materi fekal karena bakteri 
tersebut hidup di dalam saluran pencernaan manusia dan hewan berdarah panas lain (Servais et al., 2007).

Kehadiran total coliform yang tinggi di setiap stasiun disebabkan keberadaan kandungan organik yang tinggi (berada di luar kisaran baku mutu air kelas satu) dan nilai $\mathrm{pH}$ yang cenderung asam di dalam perairan. Hong et al., (2010) menyatakan keberadaan bakteri tersebut memiliki korelasi positif antara kandungan senyawa organik dan berkebalikan dengan nilai $\mathrm{pH}$. Kandungan organik yang tinggi dan nilai $\mathrm{pH}$ rendah memberikan keuntungan seperti memberikan nutrisi dan lingkungan yang sesuai untuk bakteri coliform. Armisen \& Servais (2007) melaporkan sumber kontaminasi $E$. coli permukaan perairan juga dapat berasal dari masukan limbah domestik, air lindi (leachate) dan lain sebagainya yang masuk melalui aliran air sungai yang memiliki aktivitas manusia yang tinggi di sekitarnya.

Keberadaan E. coli di dalam perairan danau juga digunakan sebagai merupakan indikator keberadaan organisme patogen seperti bakteri lain yang merupakan parasit yang hidup dalam sistem pencernaan manusia serta terkandung dalam feses (Armisen \& Servais, 2007). Salmonella merupakan genus bakteri yang menyebabkan salmonellosis. Beberapa serotype bakteri ini bersifat patogen seperti $S$. enteritidis, $S$. choleraesuis, dan $S$. typhi (Irianto, 2006).

\section{KESIMPULAN}

Kualitas fisik-kimia dan mikrobiologi (nilai $\mathrm{pH}, \mathrm{BOD}_{5}$ dan total coliform) air perairan Situ Gintung telah berada di luar baku mutu air kelas I PP. 82 Tahun 2001 dan terdapat cemaran bakteri Salmonella sp. dengan isolat yaitu $1 \mathrm{H}$, II P, II H, III H, IV H, $\mathrm{V}$ P dan $\mathrm{V} \mathrm{H}$ pada semua stasiun kecuali stasiun 6.

\section{UCAPAN TERIMA KASIH}

DIKTIS Kementrian Agama Republik Indonesia, Dr. Irawan Sugoro peneliti BATAN, teman-teman kelompok studi mikrobiologi dan molekuler (GENOM) dan staff Pusat Laboratoriun Terpadu UIN Syarif
Hidayatullah Jakarta yang telah membantu penelitian ini.

\section{DAFTAR PUSTAKA}

Ajeagah G, Njine T, Foto S. 2010. Monitoring of Organic Load in A Tropical Urban River Basin (Cameroon) by Means of BOD and Oxydability Measurements. Ecohydrology \& Hydrobiology. vol 10(1): 71-80.

Armisen TG, Servais P. 2007. Respective Contributions of Point and Non-Point Sources of E. coli and Enterococci in A Large Urbanized Watershed (The Seine River, France). Journal of Environmental Management. vol 82: 512-518.

Crowe SA, O'Neill AH, Katsey S, Hehanussa P, Haffner GD, Sundby B, Mucci A, Fowle DA. 2008. The Biogeochemistry of Tropical Lakes: A Case Study From Lake Matano, Indonesia. Limnology and Oceanografi. vol 53(1): 319-331.

Emongor V, Nkegbe E, Kealotswe B, Koorapetse I, Sankwasa S, Keikanetswe S. 2005. Pollution Indicators in Gaborone Industrial Effluent. Journal of Applied Sciences. vol 5(1):147-150.

Gerardi MH. 2006. Wastewater Bacteria. New Jersey: John Wiley \& Sons, Inc. pp 36.

Hong H, Qiu J, Liang Y. 2010. Environmental Factors Influencing the Distribution of Total Coliform Bacteria in Six Water Storage Resevoirs in the Pearl River Delta Region, China. Journal of Environmental Sciences. vol 22(5): 663-668.

Hoorman T, Hone T, Hudman S, Dirksen T, Iles J, Islam KR. 2008. Agricultural Impact on Lake and Stream Water Quality in Grand Lakes St. Marys, Western Ohio. Water Air Soil Pollution. vol 193:309-322

Huang, S, Qiao M, Wang H, Wang Z. 2006. Organchlorinated Pesticides in Surface Sediments of Meiliang Bay in Taihu Lake, China. Journal Environmental Science Health. vol 4: 223-234.

Irianto K. 2006. Mikrobiologi: Menguak Dunia Mikroorganisme. Bandung: Yrama Widya. hal 93-96. 
Jouanneau S, Recoules L, Durand MJ, Boukabache A, Picot V, Primault Y, Lakel A, Sengelin M, Barillon B, Thouand G. 2014. Methods for Assessing Biochemical Oxygen Demand (BOD): A Review. Water Research. vol 49: 62-82.

Kazi TG, Arain MB, Jamali MK, Jalbani N, Afridi HI, Sarfraz RA, Baig JA, Shah AQ. 2009. Assesment of Water Quality of Polluted Lake Using Multivariate Statistical Techniques. Ecotoxicology and Environmental Safety. vol 72: 301-309.

Manuaba IBP. 2007. Cemaran Pestisida KlorOrganik Dalam Air Danau Buyan Buleleng Bali. Jurnal Kimia. vol 1(1): 3946.

Peraturan Daerah Kota Tangerang Selatan No 15. 2011. Rencana Tata Ruamg Wilayah. Tangerang Selatan.

Pujiastuti P, Ismail B, Pranoto. 2013 Kualitas dan Beban Pencemaran Perairan Waduk Gajah Mungkur. Jurnal Ekosains. vol 5(1): 59-75.

Rochyatun E, Kaisupy MT, Rozak A. 2006. Distribusi Logam Berat Dala Sir dan Sediment di Perairan Muara Sungai Cisadane. Makara Sains. vol 10(1): 35-40.

Said NS. 2005. Metode Penghilangan Zat Besi dan Mangan di Dalam Penyediaan Air Minum Domestik. Jurnal Air Indonesia. vol 1(3): 239-250.

Sahara E. 2009. Distribusi $\mathrm{Pb}$ dan $\mathrm{Cu}$ Pada Berbagai Ukuran Partikel Sedimen di Pelabuhan Benoa. Jurnal Kimia. vol 3(2): 75-80.
Salmin. 2005. Oksigen Terlarut (DO) dan Kebutuhan Oksigen Biologi (BOD) Sebagai Salah Satu Indikator Untuk Menentukan Kualitas Perairan. Oseana. vol 30(3): 21-26.

Sener S, Davraz A, Karagüzel R. 2013. Evaluating the Anthtropogenic and Geologic Impacts on Water Quality of Egirdir Lake, Turkey. Environment Earth Science. vol 70: 2527-2544.

Servais, P, Armisen TG, George I, Billen G. 2007. Fecal Bacteria in the Rivers of the Seine Drainage Network (France): Sources, Fate and Modelling. Science of Total Environment. vol 375:152-167.

Sitorus M. 2009. Hubungan Nilai Produktivitas Primer Dengan Konsentrasi Klorofil $\alpha$, dan Faktor Fisik Kimia Di Perairan Danau Toba, Balige. Sumatera Utara. [Tesis]. Medan: Universitas Sumatera Utara.

Suriawiria U. 2008. Mikrobiologi Air. Bandung: Alumni. hal: 58 dan 79

Yazwar. 2008. Keanekaragaman Plankton dan Keterkaitannya dengan Kualitas Air di Parapat Danau Toba. [Tesis]. Medan: Universitas Sumatera Utara.

Zulkarnain I, Zulkifli H, Armanto ME. 2006. Pengelolaan Lingkungan Wisata Air Danau Ranau Di Kota Banding Agung Kabupaten Oku Selatan. Pengelolan Lingkungan dan Sumber Daya Alam. vol 4(1): 38-45. 